\title{
EFFICIENCY EVALUATION OF PRIVATE HOSPITALS IN BRAZIL: A TWO-STAGE ANALYSIS
}

\author{
THIAGO C. SAQUETTO ${ }^{1}$ \\ (iD) https://orcid.org/0000-0003-2863-1210 \\ CLÁUDIA A. S. ARAUJO \\ (iD) https://orcid.org/0000-0003-0290-4807
}

To cite this paper: Saquetto, T. C., Araujo, C. A. S. (2019). Efficiency evaluation of private hospitals in Brazil: A two-stage analysis. Revista de Administração Mackenzie, 20(5). doi:10.1590/1678-6971/ eRAMR190183

Submission: Dec. 1, 2018. Acceptance: June 12, 2019.

Instituto Federal do Espírito Santo (Ifes), Colatina, ES, Brazil.

2 Universidade Federal do Rio de Janeiro (UFRJ), Rio de Janeiro, RJ, Brazil.

\section{(cc) BY




\section{ABSTRACT}

Purpose: This study aims to describe the efficiency of private hospitals in Brazil and to understand the influence of property structure, specialization, accreditation, and teaching activity on the efficiency of private hospitals.

Originality/value: Our findings suggested that private hospitals' efficiency stands out due to their quest for quality and safety certification and investigates controversial factors in the hospital efficiency literature. Besides, it contributes to the development of the national literature as regards hospitals efficiency in Brazil through a two-stage analysis.

Design/methodology/approach: The efficiencies of 98 hospitals of the National Association of Private Hospitals (ANAHP) were estimated through the modeling Data Envelopment Analysis (DEA). Three inputs and three outputs were selected referring to the performance of hospitals in the year 2017. In the first stage, the input-oriented efficiencies were analyzed using a non-discretionary variable. In the second, bootstrapped measures were estimated, and the influences of hospital efficiency factors were investigated through econometric models.

Findings: The results enabled the description of resource management aspects related to the inputs and outputs investigated, to improve efficiency in private hospitals in Brazil, and to understand the influence of ownership, specialization, and accreditation factors on the efficiency of private hospitals.

\section{KEYWORDS}

Hospitals. Private hospitals. DEA. Accreditation. Brazil. 


\section{INTRODUCTION}

Researchers, policy-makers, and managers in the health sector have faced significant challenges related to rising costs due to the rapid adoption of technology in the sector, inefficiencies, and poor quality of health services (Mutter, Rosko, Greene, \& Wilson, 2008; Hadji, Meyer, Melikeche, Escalon, \& Degoulet, 2014). According to the World Health Organization (2010), inefficiencies are responsible for the waste of $20-40 \%$ of global health spending. Under this scenario, the availability of resources and their efficient allocation became the central concerns for health systems (O'Neill, Rauner, Heidenberger, \& Kraus, 2008).

In Brazil, a developing country of continental dimensions, with a population of more than 207 million people in 2017 (Instituto Brasileiro de Geografia e Estatística [IBGE], 2018), that lives under great social and economic inequalities, the urgency for efficient use of health resources is even higher (Araújo, Barros, \& Wanke, 2014). The country faces an aging population, with 13\% of Brazilians over 60 in 2017 (IBGE, 2017), as well as uncertainties and budgetary restrictions on health financing that threaten the sustainability of the system.

In the country, the health sector is divided into public and private systems. All Brazilians have free access to health through the Unified Health System (SUS). However, health spending accounted for only $8.9 \%$ of gross domestic product (GDP) in 2015 (World Health Organization [WHO], 2018) and the private system, responsible for $56.5 \%$ of health financing in Brazil, showed a tendency to reduce the number of resources invested: between 2011 and 2015, there was a 20\% reduction in per capita expenditures financed by the private system (WHO, 2018).

Hospitals are complex organizations that aim at multiple objectives and interests. Often these multiple objectives and interests create a conflict among professional categories, with a consequent impact on the productivity and efficiency of their processes (Hadji et al., 2014; Ferreira, Santos, Lopes, Nazareth, \& Fonseca, 2013; Hollingsworth, 2003). In 2018, Brazil had 4,841 private hospitals, corresponding to $69 \%$ of the Brazilian hospitals (Ministério da Saúde, 2018). The efficiency of Brazilian private hospitals raised the attention of several studies in recent years, especially when compared to public hospitals (Ramos et al., 2015; Trivelato, Soares, Rocha, \& Faria, 2015; Silva, Moretti, \& Schuster, 2016; Souza, Scatena, \& Kehrig, 2017). However, there are few studies devoted exclusively to evaluating the efficiency of 
private hospitals in the country (Araújo et al., 2014; Saquetto, Carneiro, Araújo, \& Figueiredo, 2017). Also, there is a diversity of empirical findings regarding the influence of ownership structure, specialization, accreditation, and teaching activity on hospital efficiency.

Due to the different configurations in terms of objectives, incentives, and control mechanisms, the influence of ownership structure on hospital efficiency remains controversial in the literature (Jehu-Appiah et al., 2014; Maredza, 2012; Roh, Moon, \& Jung, 2013; Tiemann \& Schreyögg, 2009). Specialization, on the other hand, is treated as an opportunity to maximize the profits of private hospitals when excessive contribute to reducing efficiency (Calvo, 2002). Accreditation, similarly, has been questioned as to its influence on hospital efficiency (Alexander, Wheeler, Nahra, \& Lemak, 1998; Grosskopf, Margaritis, \& Valdmanis, 2004). Moreover, the teaching activity has also been treated as a controversial issue in the face of the various empirical findings, despite the specific demands for the professionals and resources involved (Ozcan et al., 2010).

Thus, considering the importance of the theme and the gaps in the literature, this research aimed to describe the efficiency of private hospitals in Brazil, as well as to understand the influence of property structure, specialization, accreditation, and teaching activity on the efficiency of these hospitals. To achieve that, we collected data from 98 hospitals members of Associação Nacional de Hospitais Privados (ANAHP), a representative entity of Brazilian private hospitals that have or are in search of accreditation.

In order to estimate efficiency, Data Envelopment Analysis (DEA) was applied, which consists of a model distinguished by evaluating and comparing the performance of analogous organizational units, through the recognition of its multiplicity of inputs and diversity of results (Bogetoft \& Otto, 2011) and is widely applied to estimate the efficiency of health organizations (Hollingsworth, 2008; Tiemann, Schreyögg, \& Busse, 2012). After analyzing the efficiency estimates of the hospitals, data sampling procedures, named bootstrapping (Efron \& Tibshirani, 1993), were applied to investigate the influence of efficiency determinants through econometric models.

This study sheds light on the efficiency of Brazilian private hospitals since no such comprehensive study of the country's exclusively private performance exists in the literature. It also contributes to investigate the impact of factors still controversial in the literature - property structure, specialization, accreditation, and the existence of teaching activity in the institution - on the efficiency of private hospitals. Besides, so far, few national studies applied bootstrapping to address measurement errors in 
estimates within the health sector, with a focus on private hospitals (Araújo et al., 2014).

\section{INFLUENCE FACTORS IN HOSPITAL EFFICIENCY}

\subsection{Property structure}

For Property Rights Theory researchers, for-profit organizations aim to maximize the usefulness of the investment through an optimal combination of wealth generated and non-pecuniary benefits (Chang, Chang, Das, \& Li, 2004). In non-profit organizations, on the other hand, managers would be interested in maximizing aspects of the business other than those restricted to minimizing costs, therefore, contributing to increased resource consumption and consequently reducing efficiency in these organizations (Chang et al., 2004; Maredza, 2012; Mobley \& Magnussen, 1998). According to agency theory theorists, managers of non-profit organizations follow their interests, thus, maximizing the utility of the firm for personal benefit and leading to excessive consumption of non-pecuniary benefits (Chang, Mei-Ai, \& Das, 2004; Tiemann et al., 2012).

Following these theoretical propositions, part of the empirical literature indicates that private for-profit hospitals are more efficient when compared to non-profit peers. According to Tiemann and Schreyögg (2012), ownership is so critical to the performance that the shift from public to private forprofit status is associated with permanent efficiency gains in hospitals. According to this trend, the search for profit in private hospitals improves the performance of the sector (Maredza, 2012). On the other hand, some studies reported higher efficiencies in private non-profit hospitals, because they used fewer resources and presented lower unit costs (Helmig \& Lapsley, 2001; Lee, Yang, \& Choi, 2009). Despite the efforts, this evidence is inconclusive, therefore, demanding new studies on the subject (Jehu-Appiah et al., 2014).

\subsection{Specialization}

Specialized hospitals consist of organizations that provide a limited set of health services (Araújo et al., 2014). Part of the literature considers that specialization contributes to the improvement of quality and efficiency in the services provided, especially in private hospitals, although it restricts the diversity of procedures (Calvo, 2002; Gok \& Altinda, 2015). According 
to Lee, Chun, and Lee (2008), specialized hospitals tend to present higher efficiency when inserted in competitive environments where they gain advantages over competitors. However, other researchers also highlighted that excessive specialization in hospitals led to negative impacts, increase in costs, and efficiency losses (Gok \& Altinda, 2015).

\subsection{Hospital accreditation}

Accreditation is a model used to promote quality improvements in health organizations, through changes in organizational structures or processes, in the behavior of professionals and/or in the results of services rendered (Flodgren, Pomey, Tabe, \& Eccles, 2014). To receive the certification, the health organization must fulfill the requirements and invites a certifier to analyze the internal quality standards, standardized operations, and to check if the hospital attends the standard requirements. The evaluation is carried out through accredited institutions that evaluate the organization according to the formal recognition of its conformity (Rooney \& Van Ostenberg, 1999). If the hospital met the requirements, the certifier issues the certificate of quality, whose validity varies from two to three years. Although there are important distinctions among the accreditation models available, their purpose for continuous improvement is common, and there is a need for revalidation of the stamps or accreditation certificates granted (Costa, 2015; Marques, 2015).

The main hospital accreditation models currently in Brazil are: the National Accreditation Organization (ONA), divided into ONA I, ONA II, and ONA III (excellence level); the Joint Commission International (JCI); the Accreditation Canada International (ACI); and the National Integrated Accreditation for Healthcare Organizations (NIAHO). Despite the vast spread of these models around the world, there remains a concern that the benefits of accreditation may not outweigh the costs and efforts involved (Alkhenizan \& Shaw, 2011). Voluntary inspection processes, such as accreditation, rarely received an evaluation of their impacts on health organizations, contributing to literature with mixed and inconsistent results on the subject (Devkaran \& O'Farrell, 2014). According to the majority theory, accredited hospitals tend to be more efficient for disseminating a search for organizational improvement, from the adoption of established standards (Wei, 2007). On the other hand, some researchers believed that there is a negative impact on the efficiency associated with the additional demands of personnel, increased bureaucratic activities, and greater investments in 
equipment and resources to provide health services (Alexander et al., 1998; Grosskopf et al., 2004).

Consequently, previous studies and literature reviews on the effects of accreditation do not provide conclusive evidence on their impact, especially given the methodological limitations and performance measures investigated (Lindlbauer, Schreyögg, \& Winter, 2016). In addition, according to Duckett (1983) and Devkaran and O'Farrell (2014), there is a cycle through which institutions that obtain accreditation pass, which may impact in efficiency, making it necessary to analyze the results of accreditation in time series. Therefore, we still demand studies investigating the influence of accreditation, especially through models with longitudinal data (Lindlbauer et al., 2016).

\subsection{Teaching activities}

In hospitals, in addition to diagnostic, treatment, rehabilitation, and prevention services, hospitals also may develop teaching and research activities in the health field (Silva et al., 2016). Teaching and research activities contribute to increasing the social benefit of these health organizations and create an environment with its dynamics and specific demands to provide services. According to Hadji et al. (2014), teaching and research activities influence total staff costs due to their demand for professionals with seniority for the development of these activities. The association between the use of medical equipment and academic involvement implies indirect educational costs with a consequent impact on efficiency (Sato \& Fushimi, 2012). In this sense, according to Grosskopf et al. (2004), the presence of medical residents would explain a considerable part of the inefficiency in teaching hospitals. Nevertheless, inconsistent empirical findings on the subject are found in the literature, varying from studies that indicate that there is no influence of teaching activities (Colombi, Martini, \& Vittadini, 2016) to studies showing that teaching hospitals can be more efficient when compared to others without teaching activities (Nayar, Oscan, Yu, \& Nguyen, 2013).

\section{RESEARCH METHODOLOGY}

\subsection{DEA}

Among the different models for efficiency analysis, non-parametric models, such as DEA, emerged due to their flexibility to adjust to the 
complex context of hospital services (Tiemann et al., 2012). The suitability of the DEA is due to the ability to evaluate and compare the performance of similar organizations by recognizing their multiplicity of inputs and diversity of results (Bogetoft \& Otto, 2011). This has been the main tool for modeling efficiency in hospitals (Hollingsworth, 2008). The origin of the DEA is discussed in Charnes, Cooper, and Rhodes (1978), although their mathematical modeling applies concepts based on the work of Koopmans (1951), Farrell (1957), and Leibenstein (1966).

The applied model evaluates efficiency as oriented to the minimization of the consumed inputs, privileging possible reductions in the consumption of resources. The choice of model orientation depends on the extent to which managers have control over inputs and outputs analyzed. Regarding the assumptions of scale, the Constant Return Scale (CRS) model disregards the existence of economies or diseconomies of scale, computing the efficiency of a particular DMU in comparison to the best practices, among all the analyzed DMUs (Coelli, Batesse, \& Rao, 2005). When it is not possible to assume that all hospital units operate at an optimal scale, the model assumes variable assumptions - Variable Return Scale (VRS).

The assumption of variable returns compares units that operate on similar scales, whether they are increasing or decreasing, assuming that not all the factors of production have been adjusted or that some inputs are fixed. Thus, in the case of increasing returns to scale, an increase in the level of inputs (keeping constant the mix of variables) leads to a more than proportional increase in the level of outputs. However, in the case of decreasing returns to scale, an increase in the level of inputs leads to a less than proportional increase in the level of outputs (Coelli et al., 2005).

Mathematically, it is a vector of inputs $x \in R_{+}^{n}$, non-negative and not null, which produces a vector of outputs $y \in R_{+}^{m}$, non-negative and not null. The set of points that represent the combinations of factors that produce the same level of production, defined as isoquant, can be described as (Equation 1):

$$
L(y)=\left\{x \in R_{+}^{n} \mid(x, y) \in T\right\}
$$

(Equation 1)

Since $\mathrm{L}$ is a non-empty, closed set that has free availability, where all $\mathrm{x}$ can produce y. Thus, the technology can be described as (Equation 2):

$$
\mathrm{T}=\left\{(\mathrm{x}, \mathrm{y}) \in \mathrm{R}_{+}^{n+m} \mid \mathrm{x} \text { can produce } \mathrm{y} \text { in period } \mathrm{t}\right\}
$$

(Equation 2) 
Regarding the $\mathrm{T}$ boundary, called the technology or production frontier, technically inefficient DMUs operate at points within the $\mathrm{T}$ production possibilities, while those that are technically efficient operate somewhere on the technology defined by the $\mathrm{T}$ boundary, technology $\mathrm{T}$ is unobservable, under certain assumptions the data on inputs and outputs can be used as a way of approaching the true efficiency frontier (Charnes et al., 1978). In this research, the concept of efficiency used considers assumptions of the efficient set of Farrell (1957), called a weak efficiency concept by admitting scale adjustments even in the set of efficient DMUs. The subset of efficient DMUs can be described as:

$$
I=\{x \in L \mid \lambda \in(0.1) \rightarrow \lambda x \notin L\}
$$

In order to measure the relative efficiency of the hospitals concerning the best practice among health organizations investigated and according to an input-oriented model and with a non-discretionary variable, the following linear programming problem must be solved (Equation 4):

$$
\left.E\left(\left(x_{V A}^{o} \cdot x_{F I}^{o} \cdot y^{o}\right) ; T\right)=\min _{E}\left\{E x_{V A}^{o} \cdot x_{F I}^{o} \cdot y^{o}\right) \in T\right\}
$$

Thus, considering assumptions of scale with constant returns (VRS), a traditional and popular variation of the Farrell procedure makes it possible to observe the largest proportional reduction in a single input variable, where $x_{V A}^{o}$ receives contraction $\mathrm{E}$ on the variable inputs (VA) and $x_{F I}^{o}$ does not receive the contraction because they are inputs called fixed effects (FI). This leads to a simple modification of the DEA programming, described as:

$$
\begin{gathered}
\min _{E \cdot \lambda^{1}, \ldots, \lambda^{K}} E \\
\text { s.t } \quad E x_{i}^{o} \geq \sum_{k=1}^{K} \lambda^{k} x_{i}^{k} \cdot i \in V A \\
-x_{i}^{o} \geq \sum_{k=1}^{K} \lambda^{k}\left(-x_{i}^{k}\right) . i \in F I \\
y^{o} \leq \sum_{k=1}^{K} \lambda^{k} y^{k} \\
\lambda \in \ddot{\mathrm{E}}^{K}(\gamma)
\end{gathered}
$$


where $\lambda^{1}, \ldots ., \lambda^{K}$ are the varying intensities that help to construct the technological frontier $\mathrm{T}$ as the smallest convex free-ready set cone. Intuitively, $\mathrm{T}$ represents the frontier of observed best practices of the technology in the investigated period, under the premise of constant returns of scale (CRS). The assumptions of variable returns to scale (VRS), also investigated in this research, are easily included by replacing the condition of the sum of $\lambda$ by $\sum_{k=1}^{K} \lambda^{k}=1$.

\subsection{Analyzed data}

Of the 104 associated hospitals of ANAHP, the database resulted in 98 hospitals, after crossing the data available in the Observatory 2018 (ANAHP, 2018) and the National Register of Health Establishments (CNES) of Agência Nacional de Saúde Suplementar (ANS). ANAHP hospitals represent about $10 \%$ of the total private beds in the country, as well as $21 \%$ of the total supplementary health care expenses and $50 \%$ of the hospitalization expenses of the plan operators in Brazil. To remain associated with ANAHP, these hospitals must be in the process of accreditation, and, within a maximum of four years, achieve national certification at the level of excellence (ONA III) or international accreditation (ANAHP, 2018).

For the current study, three inputs and three outputs were selected (Figure 3.2.1), based on the existing literature on the analysis of hospital efficiency through DEA. The selected inputs were: 1 . operational hospital beds; 2 . registered physicians; and 3. the number of active employees. As for the number of registered doctors, however, it is necessary to indicate a differentiated methodological treatment. Due to the impossibility of safely inferring the time of dedication or the nature of the bond of the medical professionals with the investigated hospital, this variable was considered a variable of fixed effects and modeled according to non-discretionary effects. The non-discretionary efficiency analysis introduced by Banker and Morey (1986) is a mathematical model with variable constraints called exogenous variables or fixed effects that are not subject to the radial contraction process proposed by Farrell (1957). Among the selected outputs are: 1. the number of consultations in the emergency room; 2 . the number of hospitalizations; and 3. the number of surgeries. 


\section{(Figure 3.2.1)}

VARIABLES AND REFERENCES OF RESEARCH INPUTS AND OUTPUTS

\begin{tabular}{|c|c|c|}
\hline Type & Variables & References \\
\hline $\begin{array}{l}\text { Capital } \\
\text { investments }\end{array}$ & Hospital beds & $\begin{array}{l}\text { Ferrier and Valdmanis (1996), Mobley and Magnussen } \\
\text { (1998), Chern and Wan (2000), Aletras, Kontodimopoulos, } \\
\text { Zagouldoudis, and Niakas (2007), De Nicola, Gitto, and } \\
\text { Mancuso (2013), Cunha and Corrêa (2013), and Souza, } \\
\text { Scatena, and Kehrig (2016). }\end{array}$ \\
\hline \multirow[t]{2}{*}{$\begin{array}{l}\text { Human } \\
\text { resources }\end{array}$} & Medical doctors & $\begin{array}{l}\text { Grosskopf and Valdmanis (1987), Kirigia, Lambo, and Sambo } \\
\text { (2000), Aletras et al. (2007), De Nicola et al. (2013), Mogha, } \\
\text { Yadav, and Singh (2014), Souza et al. (2016), and Souza } \\
\text { et al. (2017). }\end{array}$ \\
\hline & Employees & Ferrier and Valdmanis (1996) and Cunha and Corrêa (2013). \\
\hline \multirow{3}{*}{$\begin{array}{l}\text { Hospital } \\
\text { activities }\end{array}$} & $\begin{array}{l}\text { Medical } \\
\text { consultations }\end{array}$ & $\begin{array}{l}\text { Grosskopf and Valdmanis (1987), Ferrier and Valdmanis } \\
\text { (1996), and Chern and Wan (2000). }\end{array}$ \\
\hline & Hospitalizations & $\begin{array}{l}\text { Ferrier and Valdmanis (1996), Cunha and Corrêa (2013), } \\
\text { Mogha et al. (2014), Souza et al. (2016), and Souza et al. } \\
\text { (2017). }\end{array}$ \\
\hline & Surgeries & $\begin{array}{l}\text { Ferrier and Valdmanis (1996), Aletras et al. (2007), and } \\
\text { Cunha and Corrêa (2013). }\end{array}$ \\
\hline
\end{tabular}

Source: Elaborated by the authors.

Regarding the contextual variables, named determinants of hospital efficiency in this research, hospitals are: for-profit (1) or non-profit (0); specialized (1) or general (0); with teaching activities (1) or not (0); and hospitals with accreditation at the level of excellence - ONA III or international (1) or not - hospitals without accreditation or national certification at ONA levels I and II (0).

\subsection{Bootstrapped truncate regression}

After analyzing the efficiency estimates of the hospitals, second-stage analysis techniques were applied, to regress organizational factors. Given the deterministic nature of DEA modeling, it does not allow the incorporation of a priori statistical error. Thus, the model requires adaptations that allow the extension of its sensitive nature to the sample variations of the analyzed set (De Nicola, Gitto, \& Mancuso, 2013). Thus, through a random replication process with replacement, new measures are generated for the input and output variables, and new estimates for efficiency are obtained. 
This process attributes greater robustness to the results, allowing to analyze the efficiency from an inferential statistical perspective (Blank \& Valdmanis, 2010). Following studies previously performed by Araújo et al. (2014) in the present study, 1,000 bootstrapped interactions were applied.

Hospital efficiency results, bootstrapped for bias correction, were then investigated for efficiency determinants using econometric models with Tobit regression. The Tobit regression is a truncated analysis technique that considers the efficiency variation between 0 and 1 (Blank \& Valdmanis, 2010) The relation between the determinants of the research and the efficiency is investigated according to Equation 6 , in which " $\alpha$ " represents the constant term; " $\varepsilon_{j}$ " the error; and " $Z_{j}$ " represents a vector composed of the determinants of the study. These determinants are expected to be related to the efficiency indexes of the DMUs, denominated " $E_{j}$ ", obtained according to different assumptions of scale.

$$
E_{j}=\alpha+Z_{j} \delta+\varepsilon_{j}, j=1, \ldots, n
$$

(Equation 6)

The indicated treatments were conducted through R software (https:// www.r-project.org/), through the following packages: Benchmarking (version 0.26), AER (version 1.2-5), goal (version 4.4-1), and stats (version 3.3.0).

\section{RESULTS AND DISCUSSIONS}

Figure 4.1 shows the descriptive statistics of the variables investigated.

\begin{tabular}{lrrrrr}
\multicolumn{1}{c}{ (Figure 4.1) } \\
STATISTICS OF INVESTIGATED VARIABLES, INPUT AND OUTPUT, \\
AND FACTORS
\end{tabular}

Source: Elaborated by the authors. 
The results revealed high variability among the hospitals surveyed. According to the correlation analysis, there is a high correlation between the inputs beds and employees (0.89) and between the outputs consultations and hospitalizations (0.62). Despite these results, and taking advantage of our deterministic model combined with techniques to reduce bias (bootstrapped), we decided to keep all the hospitals in the sample. Regarding the characteristics of hospitals, the final set consists of hospitals accredited at the level of excellence (79\%) and for-profit hospitals (66\%). Only $11 \%$ of the hospitals analyzed were specialized, and only $13 \%$ developed teaching activities (13\%).

Figure 4.2 summarizes the efficiency results of the hospitals analyzed.

\section{(Figure 4.2)}

\section{SUMMARY OF THE EFFICIENCY RESULTS OF THE HOSPITALS ANALYZED}

\begin{tabular}{|c|c|c|c|c|c|c|}
\hline \multirow{2}{*}{ Efficiency interval } & \multicolumn{2}{|c|}{ CRS } & \multicolumn{2}{|c|}{ VRS } & \multicolumn{2}{|c|}{ SE } \\
\hline & $\#$ & $\%$ & $\#$ & $\%$ & $\#$ & $\%$ \\
\hline Eff $=1$ & 11 & 11.22 & 18 & 18.37 & 11 & 11.22 \\
\hline $0.9<=E f f<1$ & 3 & 3.06 & 10 & 10.20 & 37 & 37.76 \\
\hline $0.8<=E f f<0.9$ & 11 & 11.22 & 10 & 10.20 & 20 & 20.41 \\
\hline $0.7<=E f f<0.8$ & 6 & 6.12 & 10 & 10.20 & 13 & 13.27 \\
\hline $0.6<=E f f<0.7$ & 7 & 7.14 & 13 & 13.27 & 6 & 6.12 \\
\hline $0.5<=E f f<0.6$ & 17 & 17.35 & 14 & 14.29 & 7 & 7.14 \\
\hline $0.4<=E f f<0.5$ & 23 & 23.47 & 16 & 16.33 & - & - \\
\hline $0.3<=$ Eff $<0.4$ & 15 & 15.31 & 6 & 6.12 & 2 & 2.04 \\
\hline $0.2<=E f f<0.3$ & 3 & 3.06 & 1 & 1.02 & 1 & 1.02 \\
\hline $0.1<=E f f<0.2$ & 1 & 1.02 & - & - & - & - \\
\hline $0.0<=E f f<0.1$ & 1 & 1.02 & - & - & 1 & 1.02 \\
\hline Average EF & \multicolumn{2}{|c|}{0.59} & \multicolumn{2}{|c|}{0.70} & \multicolumn{2}{|c|}{0.84} \\
\hline Standard deviation & \multicolumn{2}{|c|}{0.23} & \multicolumn{2}{|c|}{0.22} & \multicolumn{2}{|c|}{0.18} \\
\hline$N$ & \multicolumn{6}{|c|}{98} \\
\hline
\end{tabular}

Source: Elaborated by the authors.

The CRS model presented greater discrimination power in the efficiency results, with an average efficiency of $59 \%$. According to this model, only 
$11.22 \%$ of the hospitals investigated can be considered efficient (efficiency score 1 or $100 \%$ ) and $43.88 \%$ of the hospitals in the sample presented an efficiency equal or less than $50 \%$. Moreover, the CRS model showed that $56.13 \%$ of the hospitals investigated had an efficiency score ranging between $40 \%$ and $60 \%$. In the VRS model, the average efficiency of the hospitals in the sample was $70 \%$, in which $18.37 \%$ of the hospitals were considered efficient, and only $23.47 \%$ of the hospitals had an efficiency equal or less than $50 \%$. For this model, $43.89 \%$ of the hospitals obtained an efficiency score between $40 \%$ and $60 \%$. Therefore, the results revealed that only a small percentage of the analyzed hospitals proved to be efficient despite the analyzed efficiency models.

The low-efficiency scores found in this study are in line with previous studies with private hospitals (Araújo et al., 2014; Saquetto et al., 2017) and indicate that the origin of the inefficiency of private hospitals is not in the scale of its operations, but in structural problems. These results are corroborated by the analysis of the scale efficiency (SE), whose results indicated an average efficiency score of $84 \%$ and that $71.44 \%$ of the hospitals obtained an efficiency score greater than or equal to $70 \%$, although only 11 hospitals $(11.22 \%)$ were operating in an adequate scale of production (SE $=$ 1 or $100 \%)$. Thus, it is possible to affirm that the private hospitals analyzed should prioritize management actions to improve the efficiency of their institutions, using more efficiently the production resources investigated in this study. Figure 4.3 shows the efficiency results obtained by the hospital (CRS, VRS, and SE) and the scale returns in which hospitals operate in the period (return to scale - RTS). Also, their scale dimensions are indicated through a classification according to the number of beds and their characteristics related to the determinants investigated in this study.

\section{(Figure 4.3)}

INITIAL AND BOOTSTRAPPED EFFICIENCY ESTIMATES

\begin{tabular}{llllllllllll}
\hline Hosp. & CRS & VRS & SE & $\sum_{\lambda}$ & RTS & ACRED & FIN & ESP & ENS & $\begin{array}{c}\text { Portage } \\
\text { (hospital beds) }\end{array}$ \\
\hline H4 & 1.00 & 1.00 & 1.00 & 1.00 & Constant & 0 & 1 & 0 & 0 & 251 to 500 \\
\hline H24 & 1.00 & 1.00 & 1.00 & 1.00 & Constant & 0 & 1 & 0 & 0 & 101 to 250 \\
\hline H55 & 1.00 & 1.00 & 1.00 & 2.97 & Decreasing & 1 & 1 & 0 & 0 & 50 to 100 \\
\hline H59 & 1.00 & 1.00 & 1.00 & 1.00 & Constant & 1 & 1 & 0 & 0 & Higher than 501 \\
\hline
\end{tabular}




\section{(Figure 4.3 (continuation))}

INITIAL AND BOOTSTRAPPED EFFICIENCY ESTIMATES

\begin{tabular}{lllllllllll}
\hline Hosp. & CRS & VRS & SE & $\sum \lambda$ & RTS & ACRED & FIN & ESP & ENS & $\begin{array}{c}\text { Portage } \\
\text { (hospital beds) }\end{array}$ \\
\hline H74 & 1.00 & 1.00 & 1.00 & 1.00 & Constant & 1 & 1 & 1 & 0 & 101 to 250 \\
\hline H76 & 1.00 & 1.00 & 1.00 & 1.00 & Constant & 1 & 1 & 0 & 0 & 101 to 250 \\
\hline H79 & 1.00 & 1.00 & 1.00 & 1.00 & Constant & 1 & 1 & 0 & 0 & 101 to 250 \\
\hline H85 & 1.00 & 1.00 & 1.00 & 1.00 & Constant & 1 & 1 & 0 & 0 & 50 to 100 \\
\hline H86 & 1.00 & 1.00 & 1.00 & 3.27 & Decreasing & 1 & 1 & 0 & 0 & 251 to 500 \\
\hline H88 & 1.00 & 1.00 & 1.00 & 1.00 & Constant & 1 & 1 & 0 & 0 & 101 to 250 \\
\hline H91 & 1.00 & 1.00 & 1.00 & 1.00 & Constant & 0 & 1 & 0 & 0 & 251 to 500 \\
\hline H11 & 0.97 & 1.00 & 0.97 & 1.00 & Constant & 1 & 1 & 0 & 0 & 251 to 500 \\
\hline H41 & 0.97 & 0.99 & 0.97 & 1.36 & Decreasing & 1 & 1 & 0 & 0 & 50 to 100 \\
\hline H42 & 0.93 & 1.00 & 0.93 & 0.58 & Crescent & 1 & 1 & 0 & 0 & 101 to 250 \\
\hline H28 & 0.89 & 0.89 & 0.99 & 1.00 & Constant & 0 & 1 & 0 & 0 & 101 to 250 \\
\hline H64 & 0.88 & 0.98 & 0.90 & 1.00 & Constant & 0 & 1 & 0 & 0 & 101 to 250 \\
\hline H45 & 0.88 & 0.99 & 0.90 & 1.00 & Constant & 1 & 0 & 0 & 0 & 251 to 500 \\
\hline H77 & 0.87 & 1.00 & 0.87 & 1.00 & Constant & 1 & 0 & 0 & 0 & 50 to 100 \\
\hline H63 & 0.86 & 0.92 & 0.93 & 1.00 & Constant & 1 & 0 & 0 & 0 & 251 to 500 \\
\hline H26 & 0.83 & 0.91 & 0.91 & 1.00 & Constant & 0 & 1 & 0 & 0 & 101 to 250 \\
\hline H8 & 0.82 & 0.89 & 0.92 & 0.95 & Increasing & 0 & 0 & 0 & 0 & 50 to 100 \\
\hline H17 & 0.82 & 0.82 & 0.99 & 1.00 & Constant & 1 & 1 & 0 & 0 & 50 to 100 \\
\hline H10 & 0.81 & 0.87 & 0.93 & 1.00 & Constant & 1 & 1 & 0 & 0 & 101 to 250 \\
\hline H43 & 0.81 & 0.84 & 0.96 & 1.00 & Constant & 1 & 1 & 0 & 0 & 251 to 500 \\
\hline H18 & 0.80 & 0.95 & 0.85 & 1.00 & Constant & 1 & 1 & 0 & 0 & 101 to 250 \\
\hline H94 & 0.80 & 0.87 & 0.92 & 1.00 & Constant & 1 & 1 & 0 & 0 & 251 to 500 \\
\hline H15 & 0.76 & 0.91 & 0.84 & 1.00 & Constant & 1 & 1 & 0 & 0 & 101 to 250 \\
\hline H72 & 0.75 & 0.95 & 0.80 & 0.69 & Increasing & 1 & 0 & 1 & 0 & 251 to 500 \\
\hline & 0.73 & 0.75 & 0.97 & 1.00 & Constant & 1 & 1 & 0 & 1 & 101 to 250 \\
\hline
\end{tabular}




\section{(Figure 4.3 (continuation))}

INITIAL AND BOOTSTRAPPED EFFICIENCY ESTIMATES

\begin{tabular}{|c|c|c|c|c|c|c|c|c|c|c|}
\hline Hosp. & CRS & VRS & SE & $\sum \lambda$ & RTS & ACRED & FIN & ESP & ENS & $\begin{array}{c}\text { Portage } \\
\text { (hospital beds) }\end{array}$ \\
\hline H78 & 0.72 & 1.00 & 0.72 & 2.56 & Decreasing & 1 & 1 & 0 & 0 & 251 to 500 \\
\hline $\mathrm{H} 25$ & 0.70 & 0.75 & 0.94 & 1.00 & Constant & 0 & 1 & 0 & 0 & 101 to 250 \\
\hline H69 & 0.68 & 1.00 & 0.68 & 1.00 & Constant & 1 & 0 & 0 & 0 & 251 to 500 \\
\hline $\mathrm{H} 27$ & 0.68 & 0.71 & 0.96 & 1.00 & Constant & 1 & 1 & 0 & 0 & 251 to 500 \\
\hline $\mathrm{H} 92$ & 0.66 & 0.70 & 0.98 & 1.13 & Decreasing & 0 & 0 & 0 & 1 & 101 to 250 \\
\hline $\mathrm{H} 44$ & 0.64 & 0.85 & 0.76 & 1.00 & Constant & 0 & 0 & 0 & 0 & 101 to 250 \\
\hline H57 & 0.63 & 0.64 & 0.98 & 1.22 & Decreasing & 1 & 0 & 0 & 0 & 101 to 250 \\
\hline H53 & 0.61 & 0.63 & 0.98 & 1.00 & Constant & 1 & 1 & 0 & 0 & 251 to 500 \\
\hline H83 & 0.61 & 0.61 & 1.00 & 1.00 & Constant & 1 & 1 & 0 & 0 & 50 to 100 \\
\hline H84 & 0.59 & 0.72 & 0.82 & 1.98 & Decreasing & 1 & 0 & 0 & 0 & 101 to 250 \\
\hline $\mathrm{H} 62$ & 0.58 & 0.72 & 0.80 & 1.00 & Constant & 1 & 0 & 0 & 0 & 251 to 500 \\
\hline H87 & 0.56 & 0.83 & 0.68 & 1.00 & Constant & 1 & 0 & 0 & 0 & 101 to 250 \\
\hline $\mathrm{HI} 4$ & 0.55 & 0.55 & 0.99 & 1.00 & Constant & 1 & 1 & 0 & 0 & 101 to 250 \\
\hline $\mathrm{H} 16$ & 0.54 & 0.57 & 0.95 & 1.00 & Constant & 1 & 1 & 0 & 0 & 101 to 250 \\
\hline H39 & 0.54 & 0.59 & 0.92 & 1.00 & Constant & 1 & 0 & 0 & 0 & 101 to 250 \\
\hline $\mathrm{H} 95$ & 0.54 & 0.71 & 0.75 & 1.00 & Constant & 0 & 0 & 0 & 0 & 251 to 500 \\
\hline $\mathrm{H} 73$ & 0.54 & 0.60 & 0.89 & 1.00 & Constant & 1 & 1 & 0 & 0 & 101 to 250 \\
\hline $\mathrm{H} 90$ & 0.53 & 0.54 & 0.98 & 1.14 & Decreasing & 0 & 0 & 0 & 0 & 101 to 250 \\
\hline H56 & 0.53 & 0.63 & 0.84 & 1.00 & Crescent & 1 & 1 & 0 & 0 & 101 to 250 \\
\hline H80 & 0.53 & 0.6 & 0.87 & 1.53 & Decreasing & 1 & 1 & 0 & 0 & 50 to 100 \\
\hline $\mathrm{H} 47$ & 0.52 & 0.77 & 0.68 & 1.00 & Constant & 0 & 0 & 0 & 1 & 101 to 250 \\
\hline H6 & 0.52 & 0.59 & 0.87 & 1.00 & Constant & 1 & 0 & 0 & 1 & 251 to 500 \\
\hline H89 & 0.52 & 0.60 & 0.85 & 1.00 & Constant & 0 & 1 & 0 & 0 & 251 to 500 \\
\hline $\mathrm{H} 40$ & 0.51 & 1.00 & 0.51 & 1.00 & Constant & 1 & 1 & 1 & 0 & 251 to 500 \\
\hline H65 & 0.51 & 0.63 & 0.81 & 1.00 & Constant & 1 & 0 & 0 & 1 & 251 to 500 \\
\hline
\end{tabular}




\section{(Figure 4.3 (continuation))}

INITIAL AND BOOTSTRAPPED EFFICIENCY ESTIMATES

\begin{tabular}{lllllllllll}
\hline Hosp. & CRS & VRS & SE & $\sum \lambda$ & RTS & ACRED & FIN & ESP & ENS & $\begin{array}{c}\text { Portage } \\
\text { (hospital beds) }\end{array}$ \\
\hline H23 & 0.50 & 0.53 & 0.95 & 1.00 & Constant & 1 & 1 & 0 & 0 & 101 to 250 \\
\hline H34 & 0.48 & 0.50 & 0.97 & 1.00 & Constant & 1 & 1 & 0 & 0 & Higher than 501 \\
\hline H48 & 0.48 & 0.81 & 0.59 & 1.00 & Constant & 1 & 1 & 0 & 0 & 101 to 250 \\
\hline H1 & 0.47 & 0.61 & 0.78 & 1.00 & Constant & 1 & 0 & 0 & 1 & 251 to 500 \\
\hline H19 & 0.47 & 0.92 & 0.51 & 1.00 & Constant & 0 & 1 & 1 & 0 & 251 to 500 \\
\hline H37 & 0.47 & 0.54 & 0.88 & 1.00 & Constant & 1 & 1 & 0 & 0 & 101 to 250 \\
\hline H32 & 0.47 & 0.84 & 0.56 & 1.00 & Constant & 0 & 1 & 0 & 1 & 251 to 500 \\
\hline H98 & 0.47 & 0.76 & 0.61 & 1.00 & Constant & 1 & 0 & 0 & 1 & 101 to 250 \\
\hline H30 & 0.46 & 0.51 & 0.91 & 1.00 & Constant & 1 & 1 & 1 & 0 & 101 to 250 \\
\hline H35 & 0.46 & 0.60 & 0.77 & 1.00 & Constant & 1 & 1 & 0 & 0 & 101 to 250 \\
\hline H93 & 0.46 & 0.46 & 0.99 & 0.99 & Increasing & 1 & 1 & 0 & 0 & 251 to 500 \\
\hline H20 & 0.46 & 0.53 & 0.86 & 1.00 & Constant & 1 & 1 & 0 & 0 & 251 to 500 \\
\hline H52 & 0.46 & 0.47 & 0.97 & 1.00 & Constant & 1 & 1 & 0 & 0 & 251 to 500 \\
\hline H61 & 0.45 & 0.48 & 0.94 & 1.00 & Constant & 1 & 0 & 0 & 1 & 101 to 250 \\
\hline H67 & 0.43 & 0.54 & 0.79 & 1.00 & Constant & 0 & 1 & 0 & 0 & 251 to 500 \\
\hline H71 & 0.43 & 0.55 & 0.78 & 1.00 & Constant & 1 & 0 & 1 & 1 & 50 to 100 \\
\hline H66 & 0.42 & 0.46 & 0.92 & 1.00 & Constant & 1 & 1 & 0 & 0 & 50 to 100 \\
\hline H97 & 0.42 & 0.58 & 0.72 & 0.75 & Increasing & 1 & 1 & 1 & 0 & 101 to 250 \\
\hline H50 & 0.42 & 0.50 & 0.84 & 1.00 & Constant & 1 & 1 & 0 & 0 & 101 to 250 \\
\hline H81 & 0.41 & 0.44 & 0.94 & 1.00 & Constant & 1 & 0 & 0 & 0 & 50 to 100 \\
\hline H13 & 0.41 & 0.45 & 0.92 & 1.00 & Constant & 1 & 1 & 0 & 0 & 101 to 250 \\
\hline H31 & 0.41 & 0.78 & 0.52 & 1.00 & Constant & 0 & 1 & 0 & 0 & 101 to 250 \\
\hline H38 & 0.41 & 0.60 & 0.68 & 1.00 & Constant & 1 & 1 & 0 & 0 & 1 to 49 \\
\hline H51 & 0.41 & 0.73 & 0.56 & 0.32 & Increasing & 1 & 1 & 0 & 0 & 101 to 250 \\
\hline & 0.38 & 0.40 & 0.96 & 1.00 & Constant & 1 & 0 & 0 & 1 & 251 to 500 \\
\hline
\end{tabular}




\section{(Figure 4.3 (conclusion))}

INITIAL AND BOOTSTRAPPED EFFICIENCY ESTIMATES

\begin{tabular}{ccccccccccc}
\hline Hosp. & CRS & VRS & SE & $\sum \lambda$ & RTS & ACRED & FIN & ESP & ENS & $\begin{array}{c}\text { Portage } \\
\text { (hospital beds) }\end{array}$ \\
\hline H21 & 0.38 & 0.38 & 0.99 & 1.00 & Constant & 1 & 0 & 0 & 0 & 251 to 500 \\
\hline H3 & 0.38 & 0.42 & 0.89 & 1.00 & Constant & 1 & 1 & 0 & 0 & 101 to 250 \\
\hline H46 & 0.38 & 0.50 & 0.75 & 1.00 & Constant & 1 & 0 & 0 & 0 & 101 to 250 \\
\hline H22 & 0.38 & 0.42 & 0.89 & 1.00 & Constant & 1 & 0 & 0 & 0 & 101 to 250 \\
\hline H82 & 0.37 & 0.40 & 0.93 & 0.86 & Increasing & 1 & 1 & 1 & 0 & 50 to 100 \\
\hline H33 & 0.37 & 0.42 & 0.89 & 1.00 & Constant & 1 & 1 & 0 & 0 & 101 to 250 \\
\hline H96 & 0.37 & 0.64 & 0.58 & 0.43 & Increasing & 0 & 1 & 0 & 0 & 251 to 500 \\
\hline H9 & 0.36 & 0.92 & 0.39 & 1.00 & Constant & 0 & 1 & 0 & 0 & 101 to 250 \\
\hline H2 & 0.34 & 0.52 & 0.66 & 1.00 & Constant & 1 & 0 & 0 & 1 & 101 to 250 \\
\hline H29 & 0.34 & 0.37 & 0.90 & 1.00 & Constant & 1 & 1 & 1 & 0 & 50 to 100 \\
\hline H58 & 0.33 & 0.44 & 0.74 & 1.00 & Constant & 1 & 0 & 0 & 0 & 101 to 250 \\
\hline H49 & 0.31 & 0.32 & 0.94 & 1.00 & Constant & 1 & 1 & 0 & 0 & 101 to 250 \\
\hline H7 & 0.30 & 0.31 & 0.97 & 1.00 & Constant & 1 & 0 & 0 & 1 & 251 to 500 \\
\hline H68 & 0.30 & 0.42 & 0.72 & 1.00 & Constant & 1 & 0 & 0 & 0 & 251 to 500 \\
\hline H75 & 0.27 & 0.33 & 0.82 & 1.00 & Constant & 1 & 0 & 0 & 0 & 101 to 250 \\
\hline H12 & 0.25 & 1.00 & 0.25 & 0.08 & Increasing & 1 & 1 & 1 & 0 & 101 to 250 \\
\hline H36 & 0.20 & 0.23 & 0.89 & 1.00 & Constant & 1 & 0 & 0 & 0 & 101 to 250 \\
\hline H54 & 0.19 & 0.58 & 0.32 & 0.12 & Increasing & 1 & 1 & 0 & 0 & 101 to 250 \\
\hline H60 & 0.03 & 0.44 & 0.07 & 1.00 & Constant & 1 & 1 & 1 & 0 & Higher than 501 \\
\hline
\end{tabular}

The results presented in Figure 4.3 indicated that in the subset of hospitals with maximum efficiency ( 1 or 100\%) are not non-profit organizations or teaching activities, regardless of the efficiency assumption investigated. This subset of hospitals also contained the only specialized hospital with maximum efficiency. Regarding RTS, only two hospitals performed with decreasing returns of scale; the others acted under constant returns of scale. This finding was likely an outcome of the efficiency concept 
adopted in our research. It is a concept called weak efficiency, proposed by Farrell (1957), even among hospitals operating on the efficiency frontier, it is possible to promote improvements, in the case of hospitals with decreasing returns of scale, through adjustments in its scale dimensions.

For the larger set of hospitals investigated, by using the measures of the Scale Returns (RTS), we noticed that the majority operates under constant scale effects $(79.6 \%)$, followed by hospitals with increasing returns $(11.2 \%)$ and decreasing $(9.2 \%)$. Once again, these results reinforced the hypothesis that most of the investigated hospitals did not demand adjustments in their scale dimensions for acting under optimal scale dimensions. This is corroborated by the high rates of SE. Consequently, the observed inefficiency derived especially from the low indices of pure technical efficiency from management practices, when discounted the peculiarities of the hospital scale.

Figure 4.4 presents a description of the hospitals' efficiencies according to variable scale assumptions (VRS) and SE. The quadrants represented the stratification of hospitals in terms of mean values of SE and pure technical efficiency (VRS). Based on that, we observed, once again, little correlation between the inefficiencies from variable assumptions of VRS and the SE, reinforcing that the inefficiency of private hospitals in Brazil comes from pure technical inefficiency.

The first quadrant (QUAD I) represents the hospitals that presented technical efficiencies and scale above the average of the set, therefore, demand efficiency improvements (29.6\%). The second quadrant (QUAD II) is composed by hospitals with high efficiency of scale and low technical efficiency and, therefore, require internal improvements related to the technical procedures for the provision of health services (34.7\%). Inversely, the hospitals in the fourth quadrant (QUAD IV) demanded special attention to adjustments in the scale (19.4\%). Finally, the third quadrant (QUAD III) placed the hospitals that require both adjustments of pure technical efficiency and adjustments of efficiency of scale (16.3\%). 


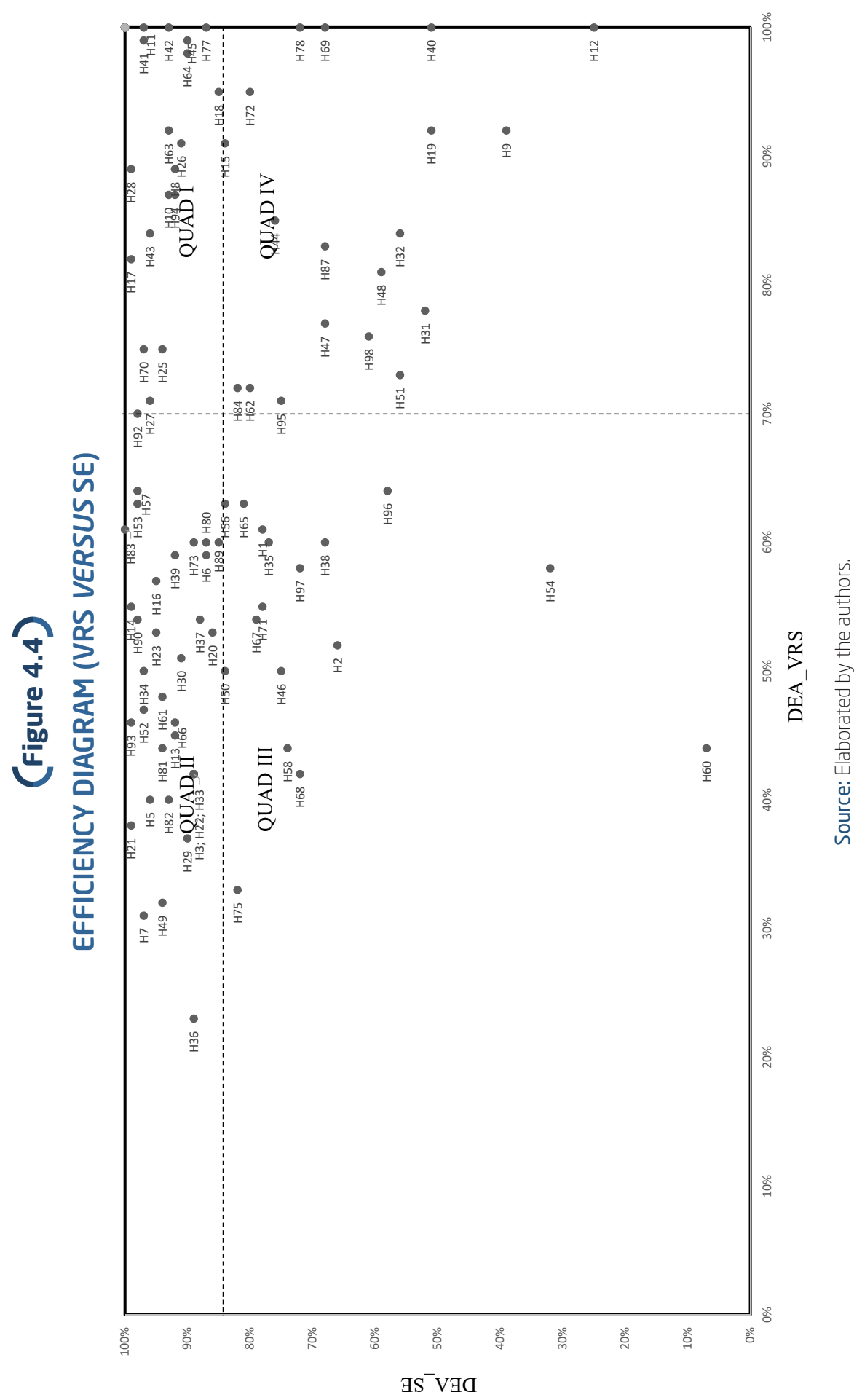


In addition to estimating the efficiency of private hospitals, the current research also investigated the impact of the accreditation variables, property structure (for-profit or non-profit), specialization, and teaching activities on hospital efficiency. Figure 4.5 shows the number of hospitals in each of these classifications.

\section{(Figure 4.5)}

CHARACTERISTICS OF THE PRIVATE HOSPITALS INVESTIGATED

\begin{tabular}{lc}
\multicolumn{1}{c}{ Feature } & Number of DMUs \\
\hline Accredited (ACRED) & 78 \\
\hline Not accredited & 20 \\
\hline For-profit (FIN) & 65 \\
\hline Non-profit & 33 \\
\hline Specialized (ESP) & 11 \\
\hline Ceneral & 87 \\
\hline With teaching activities (ENS) & 13 \\
\hline No teaching activities & 87 \\
\hline
\end{tabular}

Source: Elaborated by the authors.

Similarly, as for the findings of the second stage of our analyses, which combine bootstrapping procedures and econometric models, the results for the regression of the determinants are presented in Figure 4.6.

\section{(Figure 4.6)}

REGRESSION IN THE SECOND STAGE BOOTSTRAPPED TRUNCATED IN TWO STAGES

\begin{tabular}{|c|c|c|c|c|c|c|c|}
\hline \multirow{2}{*}{\multicolumn{2}{|c|}{$\begin{array}{l}\text { Independent } \\
\text { variables }\end{array}$}} & \multicolumn{2}{|c|}{ CRS } & \multicolumn{2}{|c|}{ VRS } & \multicolumn{2}{|c|}{ SE } \\
\hline & & Est & $\operatorname{Pr}(>|z|)$ & Est & $\operatorname{Pr}(>|z|)$ & Est & $\operatorname{Pr}(>|z|)$ \\
\hline Intercept & & 0.520 & 0.000 & 0.660 & 0.000 & 0.810 & 0.000 \\
\hline \multirow{4}{*}{ Contextuals } & ACRED & -0.050 & 0.240 & -0.120 & $0.000^{\star \star \star}$ & 0.060 & 0.190 \\
\hline & FIN & 0.060 & 0.170 & 0.070 & $0.097^{*}$ & 0.030 & 0.440 \\
\hline & ESP & -0.130 & $0.030^{* \star}$ & 0.010 & 0.870 & -0.210 & $0.000^{* * *}$ \\
\hline & ENS & -0.060 & 0.310 & -0.050 & 0.380 & -0.030 & 0.590 \\
\hline \multicolumn{2}{|c|}{ Variance of the model } & -1.720 & 0.000 & -1.800 & 0.000 & -1.070 & 0.000 \\
\hline \multicolumn{2}{|c|}{ Total of observations } & \multicolumn{2}{|c|}{1000} & \multicolumn{2}{|c|}{1000} & \multicolumn{2}{|c|}{1000} \\
\hline
\end{tabular}

$*<10 \%,{ }^{*}<5 \%,{ }^{* * *<}<1 \%$. Efficiency indices: EFF $<=1(1=100 \%)$.

Source: Elaborated by the authors. 
As showed in Figure 4.6, the results of accreditation (ACRED) revealed a significant negative impact on hospital efficiency, especially under varying assumptions of scale, with a significance level of $1 \%(p=0.000)$. This finding suggests that certification of excellence contributes to lower levels of efficiency in private hospitals, assuming that not all production factors were adjusted. Consequently, in the present research, the findings indicated that additional staffing demands, as well as investments in equipment and resources, contributed to the reduction in the efficiency of private hospitals after certification, in accordance with the findings of Alexander et al. (1998), and Grosskopf et al. (2004). However, there is a major theory that points to improvements in efficiency in accredited hospitals, including in a study conducted in Brazil with private hospitals belonging to a health plan operator (Araújo et al., 2014). This apparent contraction suggests that it may take time for the efforts to achieve accreditation to increase efficiency. These findings, therefore, emphasized the importance of investigating the impacts of accreditation over time, especially considering the possibility of efficiency gains, which may extend over the accreditation cycle, according to Duckett (1983), and Devkaran and O'Farrell (2014).

Regarding the ownership structure of hospitals (FIN), the results showed that the profit purpose positively influenced the pure technical efficiency, with a significance level of $10 \%(p=0.097)$. This result converged with the major findings presented in the literature, indicating that for-profit organizations are more efficient at maximizing the usefulness of investments when compared to non-profit peers (Chang et al., 2004; Ching-Kuo, 2007). In this sense, our results reinforced the findings of Maredza (2012), who conducted a survey in Zimbabwe and found that the search for profit in a hospital organization improved the efficiency of the sector.

Regarding the specialization (ESP), the results showed a negative impact on efficiency, with statistical significance, regarding the constant return scale model - CRS (0.030), at the level of 5\% ( $\mathrm{p}=0.030)$, and of SE, at the level of $1 \%(\mathrm{p}=0.000)$. These findings suggested that specialized hospitals had lower rates of technical efficiency $(-0.130)$, possibly due to their distinctions in terms of their scale dimensions (-0.210). According to the literature, excessive specialization contributed to increasing costs and reducing efficiency, especially due to the low SE (Gok \& Altinda, 2015). Also, specialized hospitals tend to be efficient when inserted in competitive environments, extracting advantages from their organization in relation to their competitors (Calvo, 2002; Lee et al., 2008; Gok \& Altinda, 2015), which is not the case in the Brazilian system. 
It is important to point out that specialization can generate resource idleness when the level of demand needed to occupy the resources available for production is not reached. Another aspect that deserves attention is that the classification of a specialized hospital, according to CNES, covers a broad spectrum of institutions, with different characteristics, such as oncological, maternal-infant, cardiological hospitals, and with more than one specializations. This diversity in the complexity and comprehensiveness of the services offered help to understand the inconclusive result of the studies that evaluated the impact of specialization on hospital efficiency.

In the current research, we presented the results of a study of the efficiency of hospitals with educational activities (ENS), although descriptive statistics indicated lower efficiency of these hospitals, according to the major theory (Grosskopf et al., 2004; Hadji et al., 2014; Sato \& Fushimi, 2012). The econometric findings did not point to differences with statistical significance in the efficiency of hospitals with or without teaching activity. Thus, agreeing with the findings of Colombi et al. (2016), in a study carried out in Italy. In addition, it is important to note that the role of health services in the development of health services was not adequately addressed in the previous studies of health services (Sato \& Fushimi, 2012; Hadji et al., 2014). However, in private hospitals that make up this sample, the impacts were not significant. Perhaps, the fact that it is a teaching activity in private hospitals means that managers control the number of resources. Consequently, the qualification of professionals and the quantity of demand are not so heterogeneous to impact efficiency as calculated in this research, whose model is oriented to input, that is, to reduce the number of resources to provide the same quantity of services (output). In any case, the current literature contains inconsistent empirical findings on the subject, demanding a deepening of future research, especially in the context of private health services.

\section{CONCLUSIONS}

This research described the efficiency of private hospitals in Brazil to understand the influence of property structure, specialization, accreditation, and teaching activity on the efficiency of private hospitals. Among the hospitals investigated, we observed marked distinctions in terms of technical efficiencies - CRS (mean of 59\%), pure technique - VRS (mean of 70\%) and scaling - SE (mean of $84 \%$ ), emphasizing the importance of investing in improving efficiency, in order to face the challenges in the context of private health services in Brazil. In addition, the results indicated room for quality 
improvement, since the efficiency scores were low and less than $20 \%$ of the hospitals investigated were considered efficient -1 or $100 \%$ efficiency score. According to our results, the origin of this inefficiency did not originate from the scale of its operations and was attributed to structural and management problems.

The results also indicated that private for-profit hospitals are significantly more efficient than their non-profit peers. Thus, these results corroborated the literature on the subject, which indicated that the pursuit of profit is beneficial to the efficiency of hospitals. Regarding specialization, the results indicated that it negatively influenced the efficiency of the private hospitals investigated and on the SE, although the majority of the literature postulates the benefits of specialization. These results pointed specialization as a factor that increases costs and reduces efficiency, mainly due to the low SE. Perhaps this result can be attributed to the wide range of these hospitals, in terms of the type of expertise and its complexity, and the number of specialized services offered.

The findings also pointed out that accreditation negatively influenced efficiency. Thus, these results indicated that private hospitals operating in Brazil should not expect accreditation to generate an improvement in efficiency. These results reinforced part of the literature stating that it is possible that the efforts expended to achieve accreditation produce a negative impact on hospital efficiency and that it takes time until these efforts increase efficiency. We report no statistically significant influence of teaching activities on hospitals' efficiency results. These findings contributed to the continuity of the discussion on the subject, which remains open. Perhaps the fact that private hospitals were investigated contributed to reducing the result statistical significance since these institutions control the number of resources (inputs).

This study contributed to the scientific advance by, besides describing aspects of the management of the inputs and the private provision of care (outputs) in the country, understanding the relationship between efficiency and its determinants in this important sector of the economy. In terms of the applied methodology, the study innovated by adopting cross-section research models, besides the methodological adjustments that allowed to increase the representativeness of the results and to control undesirable noises in the different phases of the study. Among the limitations, the temporal horizon of the investigation stands out. Accreditation, as it is an evaluation system through an external audit, due to the limited period of validity of the certification, requires investigation through temporal data. 
Therefore, future research should investigate accreditation and its impact before and after certification.

\section{AVALIAÇÃO DA EFICIÊNCIA DE HOSPITAIS PRIVADOS NO BRASIL: UMA ANÁLISE EM DOIS ESTÁGIOS}

\section{RESUMO}

Objetivo: Este estudo se propõe a descrever a eficiência de hospitais privados no Brasil, bem como compreender a influência da estrutura de propriedade, da especialização, da acreditação e da atividade de ensino sobre a eficiência de hospitais privados.

Originalidade/valor: Os achados descrevem a eficiência de hospitais privados que se destacam por sua busca pela certificação de qualidade e segurança, e investigam fatores controversos da literatura sobre a eficiência hospitalar. Além disso, a pesquisa contribui para o desenvolvimento da literatura nacional sobre a eficiência de hospitais no Brasil, por meio de uma análise em dois estágios.

Design/metodologia/abordagem: São estimadas as eficiências de 98 hospitais da Associação Nacional de Hospitais Privados (ANAHP) por meio da modelagem Data Envelopment Analysis (DEA). Para tal, foram selecionados três inputs e três outputs referentes ao desempenho dos hospitais no ano de 2017. No primeiro estágio, foram analisadas as eficiências, orientadas aos inputs e com a utilização de uma variável não discricionária. No segundo, foram estimadas medidas bootstrapped e investigadas, por meio de modelos econométricos, as influências dos fatores da eficiência hospitalar.

Resultados: Os resultados possibilitam descrever aspectos da gestão dos recursos, relacionados aos inputs e outputs investigados, para a melhoria da eficiência nos hospitais privados no Brasil, além da compreensão da influência dos fatores estrutura de propriedade, especialização e acreditação sobre a eficiência de hospitais privados.

\section{PALAVRAS-CHAVE}

Hospitais. Hospitais privados. DEA. Acreditação. Brasil. 


\section{REFERENCES}

Aletras, V., Kontodimopoulos, N., Zagouldoudis, A., \& Niakas, D. (2007). The short-term effect on technical and scale efficiency of establishing regional health systems and general management in Greek NHS hospitals. Health Policy, 83 (2-3), 236-245. doi:10.1016/j.healthpol.2007.01.008

Alexander, J., Wheeler, J., Nahra, T., \& Lemak, C. H. (1998). Managed care and technical efficiency in outpatient substance abuse treatment units. The Journal of Behavioral Health Services \& Research, 25(4), 377-396. doi:10.1007/ BF02287509

Alkhenizan, A., \& Shaw, C. (2011). Impact of accreditation on the quality of healthcare services: A systematic review of the literature. Annals of Saudi Medicine, 31 (4), 407-416. doi:10.4103/0256-4947.83204

Araújo, C., Barros, C., \& Wanke, P. (2014). Efficiency determinants and capacity issues in Brazilian for-profit hospitals. Health Care Management Science, 17(2), 126-138. doi:10.1007/s10729-013-9249-8

Associação Nacional de Hospitais Privados (2018). Observatório 2017. São Paulo: ANAHP.

Banker, R. D., \& Morey, R. C. (1986). Efficiency analysis for exogenously fixed inputs and outputs. Operations Research, 34(4), 513-521. doi:10.12 87/opre.34.4.513

Blank, J., \& Valdmanis, V. (2010). Environmental factors and productivity on Dutch hospitals: A semi-parametric approach. Health Care Management Science, 13(1), 27-34.

Bogetoft, P., \& Otto, L. (2011). Benchmarking with DEA, SFA, and R. New York: Springer.

Calvo, M. (2002). Hospitais públicos e privados no Sistema Único de Saúde do Brasil: O mito da eficiência privada no estado de Mato Grosso em 1998 (Tese de doutorado, Universidade Federal de Santa Catarina, Florianópolis, Santa Catarina, Brasil).

Chang, H., Chang, W.-J., Das, S., \& Li, S.-H. (2004). Health care regulation and the operating efficiency of hospitals: Evidence from Taiwan. Journal of Accounting and Public Policy, 23(6), 483-510. doi:10.1016/j.jaccpubpol. 2004.10.004

Chang, H., Mei-Ai, C., \& Das, S. (2004). Hospital ownership and operating efficiency: Evidence from Taiwan. European Journal of Operational Research, 159(2), 513-527. doi:10.1016/S0377-2217(03)00412-0 
Charnes, A., Cooper, W., \& Rhodes, E. (1978). Measuring the efficiency of decision making units. European Journal of Operational Research, 2(6), 429-444. doi:10.1016/0377-2217(78)90138-8

Chern, J., \& Wan, T. (2000). The impact of the prospective payment system on the technical efficiency of hospitals. Journal of Medical Systems, 24(3), 159-172. doi:10.1023/A:1005542324990

Ching-Kuo, W. (2007). Effects of a national health budgeting system on hospital performance: A case study. International Journal of Management, 24(1), 33-42.

Coelli, T. J., Batesse, E., \& Rao, P. (2005). An introduction to efficiency and productivity analysis (2nd ed.). New York: Springer.

Colombi, R., Martini, G., \& Vittadini, G. (2016). Determinants of transient and persistent hospital efficiency: The case Italy. Health Economics, 26(S2), 5-22. doi:10.1002/hec.3557

Costa, H., Jr. (2015). Qualidade e segurança. Rio de Janeiro: DOC Content.

Cunha, J. A. C., \& Corrêa, H. L. (2013). Avaliação de desempenho organizacional: Um estudo aplicado em hospitais filantrópicos. Revista de Administração de Empresas, 53(5), 485-499. doi:10.1590/S0034-75902013 000500006

De Nicola, A., Gitto, S., \& Mancuso, P. (2013). Evaluating Italian public hospital efficiency using bootstrap DEA and CART. International Journal of Applied Decision Sciences, 6(3), 281-292. doi:10.1504/IJADS.2013.054953

Devkaran, S., \& O'Farrell, P. (2014). The impact of hospital accreditation on clinical documentation compliance: A life cycle explanation using interrupted time series analysis. BMJ Open. doi:10.1136/bmjopen-2014-005240

Duckett, S. J. (1983). Changing hospitals: The role of hospital accreditation. Social Science \& Medicine, 17(20), 1573-1579. doi:10.1016/0277-9536(83) 90102-8

Efron, B., \& Tibshirani, R. J. (1993). An introduction to the bootstrap. (Monographs on Statistics and Applied Probability, 57). London: Chapman and Hall, CRC.

Farrell, M. J. (1957). The measurement of productive efficiency. Journal of the Royal Statistical Society: Series A (General), 120(3), 253-281. doi:10.2307/ 2343100

Ferreira, R., Santos, A., Lopes, A., Nazareth, L., \& Fonseca, A. (2013). Governança corporativa, eficiência, produtividade e desempenho. Revista de Administração Mackenzie, 14(4), 134-164. doi:10.1590/S1678-697120 13000400006 
Ferrier, G. D., \& Valdmanis, V. (1996). Rural hospital performance and its correlates. Journal of Productivity Analysis, 7(1), 63-80.

Flodgren, G., Pomey, M., Tabe, S., \& Eccles, M. (2014). Effectiveness of external inspection of compliance with standards in improving healthcare organisation behaviour, healthcare professional behaviour or patient outcomes. Cochrane Database of Systematic Reviews. doi:10.1002/14651858. CD008992

Gok, M., \& Altinda, E. (2015). Analysis of the cost and efficiency relationship: Experience in the Turkish pay for performance system. The European Journal of Health Economics, 16(5), 459-469. doi:10.1007/s10198-014-0584-6

Grosskopf, S., Margaritis, D., \& Valdmanis, V. (2004). Competitive effects on teaching hospitals. European Journal of Operational Research, 154(2), 515-525. doi:10.1016/S0377-2217(03)00185-1

Grosskopf, S., \& Valdmanis, V. (1987). Measuring hospital performance: A non-parametric approach. Journal of Health Economics, 6(2), 89-107.

Hadji, B., Meyer, R., Melikeche, S., Escalon, S., \& Degoulet, P. (2014). Assessing the relationships between hospital resources and activities: A systematic review. Journal of Medical Systems, 38(10), 1-21. doi:10.1007/ s10916-014-0127-9

Helmig, B., \& Lapsley, I. (2001). On the efficiency of public, welfare and private hospitals in Germany over time: A sectoral data envelopment analysis study. Health Services Management Research, 14(4), 263-274. doi:10.1177/095148480101400406

Hollingsworth, B. (2003). Non-parametric and parametric applications measuring efficiency in health care. Health Care Management Science, 6(4), 203-218. doi:10.1023/A:1026255523228

Hollingsworth, B. (2008). The measurement of efficiency and productivity of health care delivery. Health Economics, 17(10), 1107-1128. doi:10.1002/ hec. 1391

Instituto Brasileiro de Geografia e Estatística. (2017). Conta-satélite de saúde-Brasil: 2010-2015. Rio de Janeiro: IBGE.

Instituto Brasileiro de Geografia e Estatística. (2018). Brasil em números Brazil in figures. Rio de Janeiro: IBGE.

Jehu-Appiah, C., Sekidde, S., Adjuik, M., Akazili, J., Almeida, S., Nyonator, F., \& Kirigia, J. (2014). Ownership and technical efficiency of hospitals: Evidence from Ghana using data envelopment analysis. Cost Effectiveness and Resource Allocation, 12(9), 1-13. doi:10.1186/1478-7547-12-9 
Kirigia, J. M., Lambo, E., \& Sambo, L. G. (2000). Are public hospitals in Kwazulu-Natal Province of South Africa technically efficient?. African Journal of Health Sciences, 7(3-4), 25-32.

Koopmans, T. C. (1951). Efficient allocation of resources. Econometrica: Journal of the Econometric Society, 19(4), 455-465. doi:10.2307/1907467

Lee, K., Chun, K., \& Lee, J. (2008). Reforming the hospital service structure to improve efficiency: Urban hospital specialization. Health Policy, 87(1), 41-49. doi:10.1016/j.healthpol.2007.10.003

Lee, K., Yang, S., \& Choi, M. (2009). The association between hospital ownership and technical efficiency in a managed care environment. Journal of Medical Systems, 33(4), 307-315. doi:10.1007/s10916-008-9192-2

Leibenstein, H. (1966). Allocative efficiency vs. "X-efficiency". The American Economic Review, 56 (3), 392-415.

Lindlbauer, I., Schreyögg, J., \& Winter, V. (2016). Changes in technical efficiency after quality management certification: A DEA approach using difference-in-difference estimation with genetic matching in the hospital industry. European Journal of Operational Research, 250(3), 1026-1036. doi:10.1016/j.ejor.2015.10.029

Maredza, A. (2012). Are for-profit hospitals more efficient than non-profit hospitals? A case study of Zimbabwe using data envelopment analysis and the Tobit model. African Journal of Business Management, 6(47), 11670-11682. doi:10.5897/AJBM12.1265

Marques, S. F. (2015). Implantação do programa de acreditação de serviços de saúde. Rio de Janeiro: Medbook.

Ministério da Saúde. (2018). Cadastro Nacional de Estabelecimentos de Saúde CNES. Atualizado em nov. 2018. Recuperado de http://cnes.datasus.gov.br/

Mobley, L., \& Magnussen, J. (1998). An international comparison of hospital efficiency: Does institutional environment matter? Applied Economics, 30(8), 1089-1100. doi:10.1080/000368498325255

Mogha, S. K., Yadav, S. P., \& Singh, S. P. (2014). New slack model based efficiency assessment of public sector hospitals of Uttarakhand: State of India. International Journal of System Assurance Engineering and Management, 5(1), 32-42. doi:10.1007/s13198-013-0207-0

Mutter, R., Rosko, M., Greene, W., \& Wilson, P. (2008). Translating frontiers into practice: Taking the next steps toward improving hospital efficiency. Medical Care Research and Review Supplement, 68(1), 3-19. doi:10.1177/10 77558710384878 
Nayar, P., Oscan, Y., Yu, F., \& Nguyen, A. (2013). Benchmarking urban acute care hospitals: Efficiency and quality perspectives. Health Care Management Review, 38(2), 137-145. doi:10.1097/HMR.0b013e3182527a4c

Organização Mundial de Saúde. (2010). Financiamento dos Sistemas de Saúde: O caminho para a cobertura universal. Genebra: OMS.

O’Neill, L., Rauner, M., Heidenberger, K., \& Kraus, M. (2008). A crossnational comparison and taxonomy of DEA-based hospital efficiency studies. Socio-Economic Planning Sciences, 42(3), 158-189. doi:10.1016/j. seps.2007.03.001

Ozcan, Y., Lins, M., Lobo, M., Silva, A., Fiszman, R., \& Pereira, B. (2010). Evaluating the performance of Brazilian university hospitals. Annals of Operations Research, 178(1), 247-261. doi:10.1007/s10479-009-0528-1

Ramos, M., Cruz, L., Kishima, V., Pollara, W., Lira, A., \& Couttolenc, B. (2015). Avaliação de desempenho de hospitais que prestam atendimento pelo sistema público de saúde, Brasil. Revista de Saúde Pública, 49(43), 1-10. doi:10.1590/S0034-8910.2015049005748

Roh, C., Moon, M., \& Jung, K. (2013). Efficiency disparities among community hospitals in Tennessee: Do size, location, ownership, and network matter? Journal of Health Care for the Poor and Underserved, 24(4), 1816-1833. doi:10.1353/hpu.2013.0175

Rooney, A., \& Van Ostenberg, P. R. (1999). Licensure, accreditation and certification: Approaches to health services quality. Center for Human Services: Quality Assurance Project. Recuperado de https://www.usaidassist. org/sites/assist/files/accredmon.pdf

Saquetto, T., Carneiro, T., Araújo, C., \& Figueiredo, K. (2017). Eficiência técnica e inovatividade: Um estudo em hospitais privados brasileiros. Sistemas \& Gestão, 12(4), 410-421. doi:10.20985/1980-5160.2017.v12 $\mathrm{n} 4.978$

Sato, D., \& Fushimi, K. (2012). Impact of teaching intensity and academic status on medical resource utilization by teaching hospitals in Japan. Health Policy, 108(1), 86-92. doi:10.1016/j.healthpol.2012.08.021

Silva, M., Moretti, B., \& Schuster, H. (2016). Avaliação da eficiência hospitalar por meio da análise envoltória de dados. Revista de Gestão em Sistemas de Saúde, 5(2), 100-114. doi:10.5585/rgss.v5i2.248

Souza, P., Scatena, J., \& Kehrig, R. (2017). Eficiência hospitalar no SUS: Análise de 10 hospitais do mix público-privado do estado de Mato Grosso. Cadernos Gestão Pública e Cidadania, 22 (72), 335-354. doi:10.12660/cgpc. v22n72.66242 
Souza, P. C. D., Scatena, J. H. G., \& Kehrig, R. T. (2016). Aplicação da análise envoltória de dados para avaliar a eficiência de hospitais do SUS em Mato Grosso. Physis: Revista de Saúde Coletiva, 26(1), 289-308. doi:10.1590/S0 103-73312016000100016

Tiemann, O., \& Schreyögg, J. (2009). Effects of ownership on hospital efficiency in Germany. Business Research, 2(2), 115-145. doi:10.1007/BF033 42707

Tiemann, O., \& Schreyögg, J. (2012). Changes in hospital efficiency after privatization. Health Care Management Science, 15(4), 310-326. doi:10.1007/ s10729-012-9193-z

Tiemann, O., Schreyögg, J., \& Busse, R. (2012). Hospital ownership and efficiency: A review of studies with particular focus on Germany. Health Policy, 104(2), 163-171. doi:10.1016/j.healthpol.2011.11.010

Trivelato, P., Soares, M., Rocha, W., \& Faria, E. (2015). Avaliação da eficiência na alocação dos recursos econômicos financeiros no âmbito hospitalar. RAHIS, 12(4), 62-79. doi:10.21450/rahis.v12i4.2725

Wei, C. (2007). Effects of a national health budgeting system on hospital performance: A case study. International Journal of Management, 24(1), 33-42.

World Health Organization (2010). Financiamento dos Sistemas de Saúde: O caminho para a cobertura universal. Genebra: WHO.

World Health Organization (2018). Health spending. Recuperado de http:// www.who.int/en/

\section{AUTHOR NOTES}

Thiago C. Saquetto, Programa de Pós-Graduação em Ciências Contábeis (PPGCon), Universidade Federal do Espírito Santo (Ufes); and Cláudia A. S. Araujo, Instituto Coppead de Pós-Graduação e Pesquisa em Administração, Universidade Federal do Rio de Janeiro (UFRJ).

Thiago C. Saquetto is now professor at the Coordenadoria de Administração at Instituto Federal do Espírito Santo (Ifes); Cláudia A. S. Araujo is now professor at the Instituto Coppead de Pós-Graduação e Pesquisa em Administração at Universidade Federal do Rio de Janeiro (UFRJ).

Correspondence concerning this article should be addressed to Thiago C. Saquetto, Avenida Arino Gomes Leal, 1700, Santa Margarida, Colatina, Espírito Santo, Brazil, CEP 29700-558.

E-mail: saquetto@ifes.edu.br 
Thiago C. Saquetto, Cláudia A. S. Araujo

\section{EDITORIAL BOARD}

Editors-in-chief

Janette Brunstein

Silvia Marcia Russi de Domênico

Associated Editor

Rafael Porto

Technical Support

Vitória Batista Santos Silva

\section{EDITORIAL PRODUCTION}

Publishing Coordination

Jéssica Dametta

Layout Designer

Emap

Graphic Designer

Language Editor

Daniel de Almeida Leão
Libro 